\title{
AN INTERPERSONAL MEANING ANALYSIS OF AHOK'S BLASPHEMY CASE IN ONLINE NEWS PORTALS
}

\author{
Teti Kartika \\ Department of English Education, Faculty of Teacher Training and Education, University of Kuningan, \\ Indonesia \\ Email: karthikatetty@gmail.com \\ Marwito Wihadi \\ Department of English Education, Faculty of Teacher Training and Education, University of Kuningan, \\ Indonesia \\ E-mail: m_wihadi@yahoo.com
}

APA Citation: Kartika, T., \& Wihadi, M. (2018). An interpersonal meaning analysis of Ahok's blasphemy case in online news portals. Indonesian EFL Journal, 4(1), 89-92. DOI: 10.25134/ieflj.v4i1.888.

Received: 15-11-2017

Accepted: 29-12-2017

Published: 01-01-2018

\begin{abstract}
This research presents an interpersonal meaning analysis of two online news concerning Ahok's blasphemy case in the two online news portals. The two selected news coming from The Jakarta Post and Republika.co.id were analyzed to find out the mood types and to describe the underlying reason of the news from the differences of modality system. This descriptive qualitative research involved the analysis of mood and modality types of clauses identified. As results, it shows that the interpersonal meaning was applied. Yet, not all mood or modality types appeared in the two online news. There is only one mood and one modality type appeared, namely indicative which is declarative type and modalization which is probability type. Therefore, it can be concluded that both writers used the same mood and modality types in the online news of Ahok's blasphemy case as well as their interpersonal meaning are determined by contextual factors such as the aims or needed in giving information about the news event of Ahok's blasphemy case in Indonesia.
\end{abstract}

Keywords: Interpersonal meaning, Ahok, blasphemy case, online news

\section{INTRODUCTION}

Interpersonal meaning here concerns with the relationship between writers and readers as a part of an interactants in a news event in the online news portals. Based on Halliday and Matthiessen (2014, p. 134) "...another aspect of the meaning of the clause, its interpersonal meaning as an exchange. Here the principal grammatical system is that of MOOD." It means that interpersonal meaning as an exchanging meaning in the language used could be analyzed by using Mood system through analyzing clauses that are realized in the structure of Mood.

Further, Mood system analysis of the clause provides interactants involved in the dialogue with the resources for giving or demanding a commodity, either information or goods-\&-services (Halliday \& Matthiessen, 2014). It means that the clause analysis of the online news texts involved an interactans between the addressor to the addressee with regards whether that clause is involved a commodity exchange either an information or goods-\&-services. Thus, the clause takes a vital place in the semantic level either a proposition or a proposal. If language is used to exchange a commodity of information, the clause takes place as a proposition, while if language is used to exchange a commodity of goods-\&-services, the clause takes place as a proposal.

Furthermore, according to Halliday and Matthiessen (2014), modality is the speaker judgement, or request of the judgement of the 
listener, on the status of what is being said. It means that modality is the most important system in social communication. It can objectively express the addressor's judgement toward the topic and it shows the social relationship, scale of formality and formal relationship. Thus, through modality system analysis, it shows that, in written language, it is important to use language in right way. Then, it can provide meaning in relationship with other people and here is relationship between the writer as the addressor in the online news and the reader as the addressee.

In addition, related to the data source, the researcher chooses an interpersonal meaning analysis of Ahok's blasphemy case in online news portals because these topic was interesting to be analysed. Then, another reason was because the case was happening in Indonesia and became a polemic either in certain groups of people or among people in Indonesia widely. Through analyzing clauses from aspect of interpersonal meaning in the online news portals, either mood or modality system, the researcher could analyze the mood types applied and the differences of modality system used in the data source.

Meanwhile, related to the data source, the researcher made the scope of the study which makes this research become more specific in the analysis. The limitation was in the online news portals taken from two online news portals; the first was The Jakarta Post and the second was Republika.co.id. Further, from both online news portals, the researcher only chooses one online news which has the same topic and publishing time. In The Jakarta Post, the news entitled "Religious Expert Says Ahok's Remarks Blasphemous" and in Republika.co.id. the news entitled "Expert Witness Says There is Misguidance in Ahok's Speech". Both of the news published on Tuesday, February 21 ${ }^{\text {st }}, 2017$.

\section{METHOD}

This descriptive qualitative research used documents as the main data source in which it consists of two online news with the same topic and publishing time. The news was about Ahok's blasphemy case which was taken from two different online news portals on the internet: The Jakarta Post and Republika.co.id. The first news was taken from The Jakarta Post entitled "Religious Expert Says Ahok's Remarks Blasphemous", published on Tuesday, February $21^{\text {st }}, 2017$ at $04.30 \mathrm{pm}$. Then, the second news was taken from Republika.co.id entitled "Expert Witness Says There is Misguidance in Ahok's Speech", published on Tuesday, February $21^{\text {st }}, 2017$ at $07.19 \mathrm{pm}$.

Analyzing the collected data involves several steps, including segmenting, analyzing, and recapitulating. First step was segmenting both online news texts into the clauses in which the researcher classified the data into some clauses. The second step was analyzing the data by using functional grammar approach which focused on Mood and modality types. The last step was recapitulating the data and deciding the dominant of mood and modality types appeared in the texts. After that, the researcher described the underlying reason of the news texts from the differences of Modality system used.

\section{RESULTS AND DISCUSSION}

Halliday and Matthiessen (2014) propose there are two main types of Mood system, those are indicative and imperative. In this research, the researcher found one of mood and modality types from both online news selected that was taken from two online news portals; The Jakarta Post and Republika.co.id. The percentage of mood type in the two online news portals is shown in the table below.

Table1. The percentage of mood type

\begin{tabular}{|c|c|c|c|c|}
\hline No. & \multicolumn{2}{|c|}{ Mood Type } & Occurrence & Percentage (\%) \\
\hline \multirow[t]{2}{*}{1.} & Indicative & Declarative & 46 & 100 \\
\hline & & Interrogative & 0 & 0 \\
\hline 2. & Imperative & & 0 & 0 \\
\hline
\end{tabular}




\begin{tabular}{ccc}
\hline Total & 46 & 100 \\
\hline
\end{tabular}

From the table, it can be seen that there is only one mood type found which was an Indicative type realized by declarative. The researcher found 46 clauses (100\%) out of 46 caluses belonging to declarative. While, other types of Indicative, an interrogative type either Yes/No interrogative or WH- interrogative, were not found in any clause. Thus, the percentage was $0 \%$ with 0 occurrence. Further, in another primary type of mood system, it was Imperative type, the result shows that the percentage of the Imperative type was $0 \%$ with 0 occurrence of the clause from total 46 clauses.

Further, the result of the data refers to the information commodity, it means that the statement occurred in the data analysis mostly appeared in the clauses. Thus, these results described that the role of the writer refers to the giving information as commodity being exchanged which is realized by creating statements. The percentage of modality type in the two online news portals is shown in the table below.

Table 2. The percentage of modality type

\begin{tabular}{ccccc}
\hline No & \multicolumn{2}{c}{ Modality Type } & Occurrence & Percentage (\%) \\
\hline 1. & Modalization & Probability & 5 & 100 \\
& & Usuality & 0 & 0 \\
\multirow{2}{*}{ 2. } & Modulation & Obligation & 0 & 0 \\
& & Inclination & 0 & 0 \\
& Total & 5 & 100 \\
\hline
\end{tabular}

Based on the percentage of modality type in the two online news portals above, the researcher found that the expression of probability reflected trough modal finite became the only one modality type used, with 5 times occurrences $(100 \%)$ from total of 5 clauses. It can be concluded that there was only one modalization type used which belong to probability type.

Further, since there was no difference in the modality type used, the difference only lies in the way the writers forms the clauses in which it refers to the writer's or speaker's judgment or opinion to the preposition in the clauses. As Halliday and Matthiessen (2014) say modality is the speaker's judgment, or request of the judgment of the listener, on the status what is the speaker being said. Thus, in writing the news, the writers gave their judgments, or assessments on the topic or event in the news.

Finally, the overall results of data analysis were described clearly in the following chart.

Figure. 1 The result of the data analysis

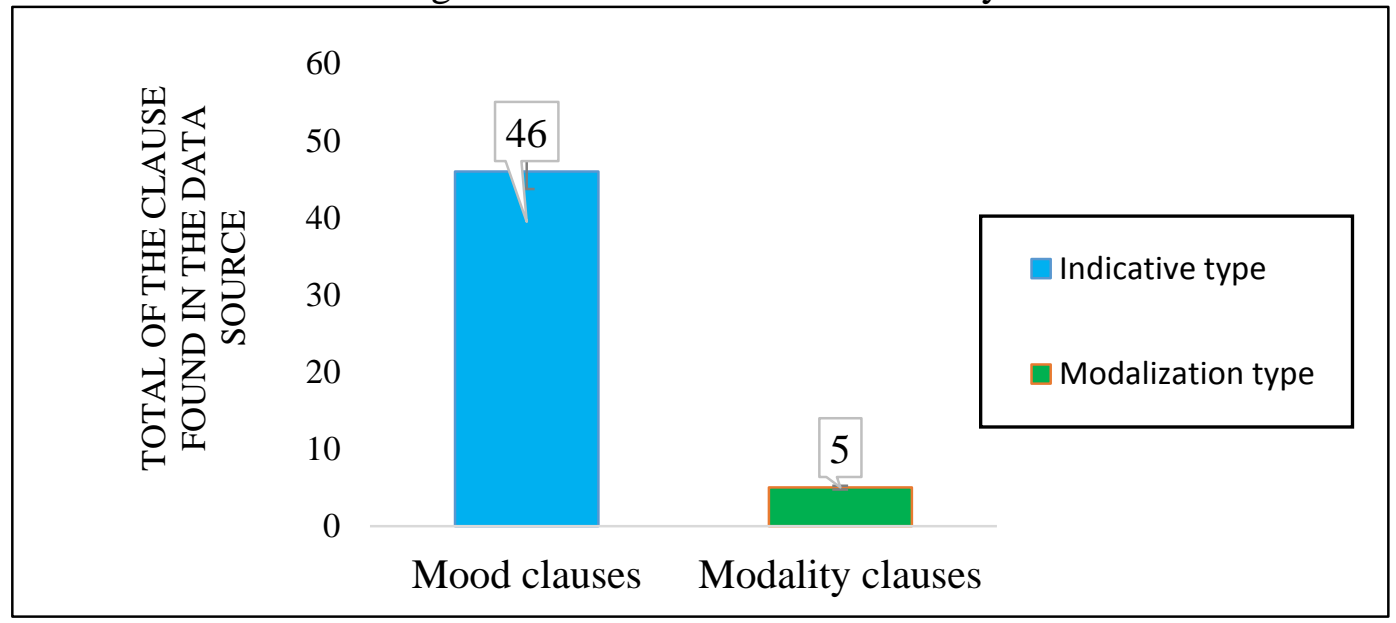


The data shows that there were 46 mood clauses identified out of 46 clauses. All the clauses identified belong to indicative mood type realized by declarative with percentage $100 \%$. Further, there were 5 clauses $(100 \%)$ of Modalization type that is categorized as the probability type.

Related to the objectives of the research, the reason behind the result in the data analysis in which it was only found one mood type and one modality type because the data was the news text. As Farooq (2015) says the news should be designed to impart some sort of information to the readers and news is a truly, concise and accurate report of the event. Furthermore, Halliday and Matthiessen (2014) add modality is the speaker's judgment, or request of the judgment of the listener, on the status what the speaker is being said.

There are a lot of research related to the analysis of interpersonal meaning that were conducted with different subject and object of the research. Therefore, the researcher used some previous studies as references in this research in order to compare the results of this research with another research relating to interpersonal meaning analysis. Those researches were conducted by Ayoola and Olusanya (2013), Sujatna (2013), Setyowati (2016), Syah (2015), and Huang. (2014). From those previous studies, the researcher found that some of those researches revealed only one mood and modality type in the data. It could be happened probably because the data source in this analysis is news that refers to the fact of an event.

\section{CONCLUSSION}

There is one mood type found from the two primary types; Indicative and Imperative mood types. The mood type found was the Indicative mood type. The result of the data analysis shows that from the Indicative mood type, the researcher only found declarative mood type in the data. In other words, the writer of the news intends to provide information to the readers by creating the declarative mood type. Further, the researcher also found only one modality type used in the data. From two modality types; the modalization and modulation types, both of the writers applied the same modality type, it was the modalization type which had characteristic as the probability type. In other words, the writer from both online news portals; The Jakarta Post and Republika.co.id used the same modalization type which belongs to probability type. The modality type used in both data source was similar, it is because the modality is speaker's judgment or assessment hence the writers of the news providing the information based on the fact in the news event, not to give their opinion or desire to the topic in the news.

Briefly, language is used in the interaction between the speakers either the addressor or the addressee. Then, the system of Mood and Modality are the keys to understand the interpersonal relationship between them. Thus, by looking at the choice of mood and modality type used, the language could not learn only in a text material but actually it could serve as meaningful materials that could be explored contextually and semantically.

\section{REFERENCES}

Ayoola, \& Olusaya, M. (2013). An interpersonal metafunction analysis of some selected political advertisements in some Nigerian newspapers. International Journal of Humanities and Social Science, 3(8), 165-178.

Farooq, U. (2015). What is news meaning definition and sources of news. Retrieved from http://www.studylecturenotes.com/journalismmass-communication/what-is-news-meaningdefinition-and-sources-of-news.

Halliday, M.A.K., \& Matthiessen, C.M.I.M. (2004). An introduction to functional grammar. London: Hodder Arnold.

Halliday, M.A.K., \& Matthiessen, C.M.I.M. (2014). Halliday's introduction to functional grammar. London, New York: Routledge publishers.

Halliday, M.A.K., \& Webster, J. (2009). Continuиm companion to systemic functional linguistics. London, New York: Continuum.

Huang, K.Z. (2014). Snip-Snap: An Analysis of Interpersonal Meaning in a Political TV Interview. International Journal of English Linguistics, 4(5).

Setyowati, L.A. (2016). Interpersonal meaning analysis in short story of hans christian andersen the real princes (Master's thesis). Retrieved from http://eprints.ums.ac.id/43254/17/NASKAH\%20P UBLIKASI.pdf

Sujatna, E.T.S. (2013). Mood system and transitivity of the airlines slogan a comparison of national and regional airlines. International Journal of English Linguistics, 3(3), 42-52. 